\title{
Phytosociology Of Echinops Giganteus In The Western Highland Of Cameroon
}

ESJ Natural/Life/Medical Sciences

\section{Christiana Ngyete Nyikob Mbogue,}

Department of Plant Biology, Faculty of Science University of Dschang, Cameroon

\section{Anjah Mendi Grace,}

Department of Plant Biology, Faculty of Science University of Dschang, Cameroon

\section{Wouokoue Taffo Junior Baudoin,}

Department of Biological Sciences, Faculty of Science, University of Maroua, Cameroon

\section{Nkemnkeng Francoline Jong,}

Department of Plant Biology, Faculty of Science University of Dschang, Cameroon

Submitted: 23 October 2020

Accepted: 23 December 2020

Published: 31 December 2020

Corresponding author:

Christiana Ngyete Nyikob Mbogue

DOI: $\underline{10.19044 / \text { esj.2020.v16n36p345 }}$

(c)

Copyright 2020 Ngyete Nyikob Mbogue C,

Distributed under Creative Commons

BY-NC-ND 4.0 OPEN ACCES

\section{Cite as:}

Ngyete Nyikob Mbogue C, Anjah Mendi G, Wouokoue Taffo Junior B, Nkemnkeng Francoline J. (2020). Phytosociology Of Echinops Giganteus In The Western Highland Of Cameroon. European Scientific Journal, ESJ, 16 (36), 1. https://doi.org/10.19044/esj.2020.v16n36p345
Abstract
Echinops giganteus (Asteraceae) is a shrub native to Cameroon, and it exists in the "wild" state in village territories. It is of potential interest to the perfume industry and is occasionally exploited for culinary (condiment) and medicinal uses. The poor management of the natural environment of Echinops giganteus, accompanied by uncontrolled intensive agriculture, has led to several consequences. The natural vegetation and soil has also been severely degraded. A field study was conducted to investigate the floristic composition and ecological spectrum of plants that live in association with Echinops giganteus using the phytosociology approach of BraunBlanquet. Assessment of the floristic composition was done in 45 plots of $25 \mathrm{~m}^{2}$ in a savannah vegetation system. Plant species identified were characterized by floristic diversity and functional traits (growth forms, life forms, diaspores types, dispersal syndromes and phytogeography). The flora consisted of 121 plant species belonging to 91 genera and 34 families. Asteraceae (24 species), Poaceae (23 species) and Fabaceae (22 species) were classified as the richest families. The species diversity indices were: Simpson (0.06), Shannon-Weaver (6.92), and Species evenness (0.70). The most frequent life forms were chamaephytes (38.93\%) and the least were therophytes (12.61\%). Microphylls (26.05\%) was the most dominant leaf size. Anemochory (50.42\%) was the dominated dispersal syndrome while the least was zoochory (13.88\%). Investigation of the geographical distribution indicated that $29.41 \%$ belonged to pantropical species. Effective conservation cannot be obtained without a thorough knowledge of the ecosystems present in an area. Consistent 
vegetation classifications and descriptions form the basis of conservation and monitoring exercises to maintain biodiversity.

Subject: Plant Biology

Keywords: Echinops Giganteus, Floristic Diversity, Ecological Spectrum, Phytosociology

\section{Introduction}

The current destruction of biodiversity is a cause for alarm while disappearance, massive degradation, and alteration occur due to intense development oriented anthropogenic activities (Krishnamurthy et al., 2010). Phytosociology is the study of the characteristics, classification, relationship, and distribution of plant communities. Therefore, such data can be collected and used to describe the population dynamics of each species studied and how they relate to the other species in the same community. Phytosociological studies are essential for protecting the natural plant communities and biodiversity, understanding the changes experienced in the past, and continuing into the future. Most of the developed countries have these basic studies (Hamzaoglu, 2005), which have been defined with the help of vegetation maps (Tel et al., 2010). However, most forests are under immense anthropogenic disturbances and require careful management intervention to maintain overall biodiversity and sustainability (Kumar et al., 2006). The genus Echinops is of the Asteraceae family and consist of about 120 species distributed world-wide (Garnatje, 2006). Echinops giganteus has been designated as a non-forest timber product (NTFP) in the Congo Basin, and the part exploited is the root (Tchatat, 1999). The roots have diverse uses spanning from medicinal, culinary to industrial (Noumi, 1984; Menut, 1997). The root of this plant is used to treat heart and gastric troubles (Tene, 2004). Also, the root has aromatic properties and has been collected and distilled to obtain essential oils which are used in synergy with those from other plants to eradicate weevils in stored grains (Ngamo, 2007; Pérez, 2010). This species is also of interest to the fragrance and flavour sectors (Menut, 1997).

The main problem with $E$. giganteus is that, despite all its importance and its conservation status as a nearly threatened species, no implementation of conservation, management, and sustainable use strategies have been put in place for it. This is due to the lack or insufficient scientific data on their biology. This general absence of information is particularly related to lack of experience in the Sub-Saharian zone of expertise and infrastructures to carry out inventories of biodiversity and mainly the characterization of the species. 
In the current research, investigation studies were carried out to examine phytosociological and species diversity. The main purpose of the phytosociological analysis was to understand floristic vegetation characteristics and to estimate the species richness and diversity which already exists in the study area.

\section{Materials And Methods}

This study was carried out in the Western Highlands of Cameroon, and part of the study was carried out in the Eastern slope of the Bamboutos Mountain located between $5^{\circ} 30^{\prime}-5^{\circ} 45^{\prime} \mathrm{N}$ and $10^{\circ} 03^{\prime}-10^{\circ} 15^{\prime} \mathrm{E}$ (Figure 1a). This mountain with its maximum height of $2740 \mathrm{~m}$ is one of the major volcanic mountains in Cameroon. The climate is defined as Cameroonian altitude type, with a long rainy season (March-November) and a short dry season (December-February). The annual average rainfall varies according to the relief from 1750 to $2500 \mathrm{~mm}$ yearly. The annual average temperature varies from $10-12$ to $23.5^{\circ} \mathrm{C}$. The predominant soils are andosols, andic ferralitic soils, and battleship ferralitic soils (Tematio et al., 2004). The herbaceous stratum is dominated by Pennisetum purpureum and Imperata cylindrica. The ligneous cover is strongly influenced by anthropogenic activities (agriculture and pasture) (Wouokoue, 2017a and b), while the other part of the floristic inventory was carried out in Dschang situated in the Menuoa Division in the Western Region of Cameroon (Figure 1b). It has geographic coordinates, latitude $5^{\circ} 26^{\prime} \mathrm{N}$, longitude $10^{\circ} 26^{\prime} \mathrm{E}$, and an altitude of $1,400 \mathrm{~m}$. According to the data of the meteorological station of the IRAD of Dschang, there is an equatorial climate characterized by an average annual temperature of $20.1^{\circ} \mathrm{C}$ while annual rainfall is $2000 \mathrm{~mm}$ on average (Aghofack, Nguemezi and Tatchago, 2010).

The vegetation consists to a large extent of savannah grassland, with the Poaceae forming the main vegetation layer. It is also interspersed with a few other annuals, biennials, and perennials trees (Ngwa, 1979). According to Aswingnue (2003), the vegetation of this region is both natural and cultivated. The cultivated vegetation consists of planted trees such as Cola accuminata, Eucalyptus globulus, Raphia hookeri and other fruit trees. Eucalyptus globulus lies mostly in the low lying plains while woody valley and natural forest exist in the watershed area (Helvetas, 2001).

The soil texture is silt-clay-loam which makes it very fertile for agricultural activities in the area (Suh et al., 2015). The soil fertility is as a result of humus, which is a dark volcanic soil from the uplands/hilly areas that has been washed down from the hills and deposited on river banks or beds of streams (Helvetas, 2001). 
Figure 1. Map of the study plots on the Bamboutos Mountain (a) and in Dschang (b)

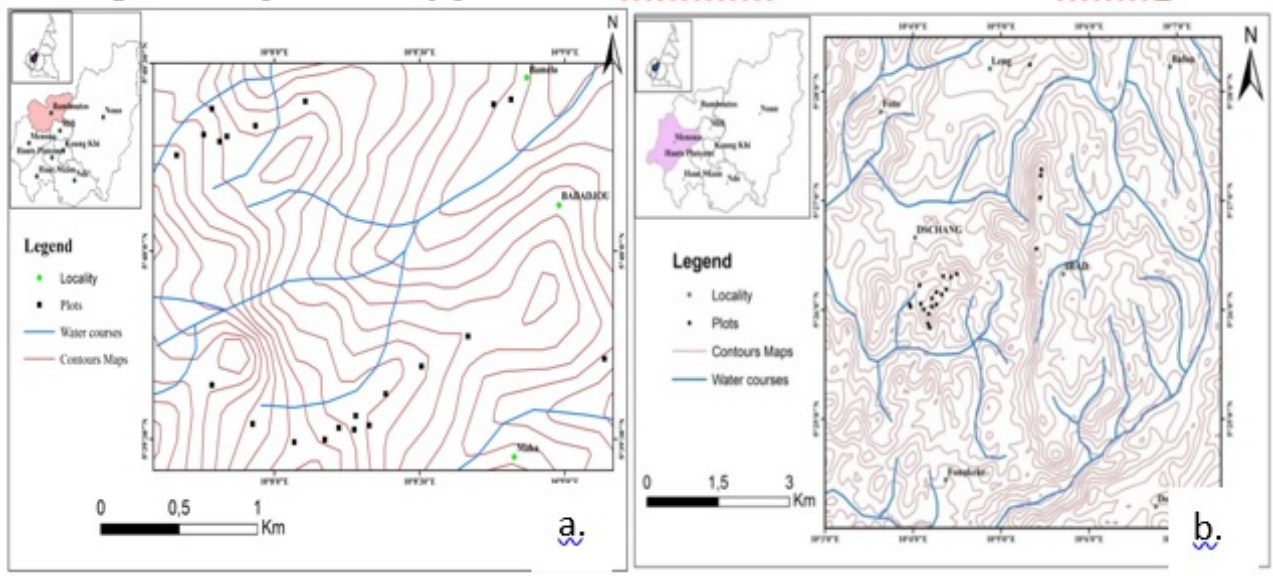

Source: Research geographic coordinates

\section{Methods}

\section{Sampling}

The vegetation sampling was done according to the method of BraunBlanquet (1932) using mixed sampling. Floristic inventory was done in the months of October and November 2018 and in July 2020. Plant species were

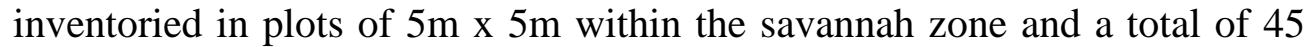
plots were sampled. Echinops giganteus was the reference point for a quadrat to be made.

Plants species were identified with the help of flora of Cameroon (Aubreville, 1998; Van der Zon, 1992). The voucher specimen was placed in the national herbarium of Cameroon. The habitat of the plant's species was determined in the field by the observation of plants. Life form were determined and classified according to Raunkiaer (1934). Leaf size were also determined and classified according to Ohsawa (1995). The types and modes of diaspore dispersal were determined and classified according to morphological criteria of Dansereau and Lems (1957). The phytogeographical distribution types that were adopted correspond to the major chorological subdivisions accepted for Africa according to White (1986). The plant nomenclature system adopted was the APGIII. The Red List of threatened species in Cameroon was used to establish IUCN conservation status of species (Onana, 2011).

\section{Data Analysis}

The data collected was entered in Excel 2010 tables and the following was calculated: taxonomic richness, species abundance, species frequency, and diversity indices.

- The taxonomic richness was expressed in number, gender, and families of the species 
- Relative Frequency $(\%)=$ Number of quadrates in which species occurs x 100

Total number of quadrates

- The relative abundance is the ratio of the total number of individuals of this taxon to the total number of individuals in all surveys.

- The Shannon-Weaver Diversity Index ( $\left.\mathrm{H}^{\prime}\right)$.

$$
H^{\prime}=-\sum_{i=1}^{s} \frac{N_{i}}{N} * \log _{2}\left(\frac{N_{i}}{N}\right)
$$

Where, $\mathrm{Ni}=$ number of individuals of species $\mathrm{i}$

$\mathrm{N}=$ total number of all species

$\mathrm{H}^{\prime}=$ Shannon diversity index in bits

- Piélou evenness index

$\mathrm{EQ}=\mathrm{H}^{\prime} / \log _{2} \mathrm{~S}$

Where, $\mathrm{H}^{\prime}$ = Shannon diversity index in bits

$\mathrm{S}=$ Number of species present in the survey

- The Simpson diversity index (Simpson, 1949).

Where, $\mathrm{Ni}=$ number of species $\mathrm{i}$

$$
D=\sum_{i=1}^{s} \frac{N i(N i-1)}{N(N-1)}
$$

$\mathrm{N}=$ total number of all species

\section{Results}

\section{Variety and Flora Composition}

This study has enumerated 121 plant species that live in association with E. giganteus. These plants are shared out among 91 genera and 34 families (APG III), and the most important are Asteraceae (20\%), Poaceae (19\%), and Fabaceae (18\%). The remaining families were of very low representation, since they had 5 or less than 5 number of species present (Figure 3).

These plant species were recorded in 45 plots from the study area, and the average value of the following diversity indices were calculated. The Shannon-Weaver diversity index was 6.92 , Simpson index was 0.06 , and the Evenness index was 0.70 . 
Figure 3. Diversity of the most represented families in the study plots.

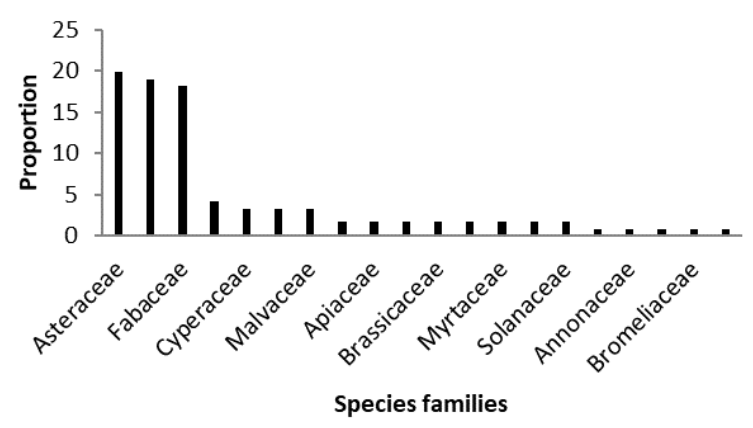

\section{Relative Frequency of the Species Studied in the Plots}

Figure 4 below shows species with above $30 \%$ of relative frequency around E. giganteus. From the figure, it is obvious that E. giganteus has the highest value since the plots were made with reference points being Echinops. More so, it is important to know the plants that live in association with $E$. giganteus. Thus, Aspilia Africana had the highest frequency with a relative frequency of $89 \%$, followed closely by Imperata cylindrica, Solidago virgaurea, and Melinis minutiflora with relative frequencies above $60 \%$. Cassia mimizoides had a relative frequency value of $58 \%$. This was followed by Dissotis princeps, Erigerom floribundus, Pteridium aquilinium, and Hyparrhenia involucrata with relative frequencies above 40\%. Subsequently, Desmodium repandum, Aspleneum abyssinicum, Laggera pterodonta, Bidens pilosa, Centella asiatica, and Pennisetum pupureum had relative frequencies above $30 \%$ around $E$. giganteus.

Figure 4. Relative frequency of species greater than $30 \%$

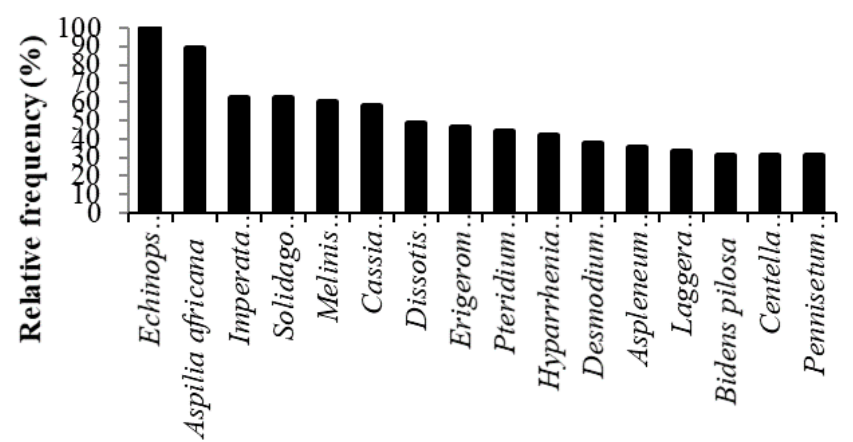

Species

\section{Relative Abundance of Species in the Study Plots}

Figure 5 shows species with above $2 \%$ of relative abundance around E. giganteus plant. Melinis minutiflora and Imperata cylindrica had relative 
abundance of above $14 \%$. This was followed closely by Hyparrhenia involucrata with relative abundance of $8.5 \%$, while Dactylon sp had relative abundance of $6.3 \%$.

Echinops giganteus, Pteridium aquilinium, Aspilia Africana, Solidago virgaurea, and Kotchya strigosa had relative abundance of above $3 \%$, while Aspleneum abyssinicum, Desmodium repandum, and Erigerom floribundus had relative abundance of above $2 \%$.

Figure 5. Relative abundance of species more than $2 \%$

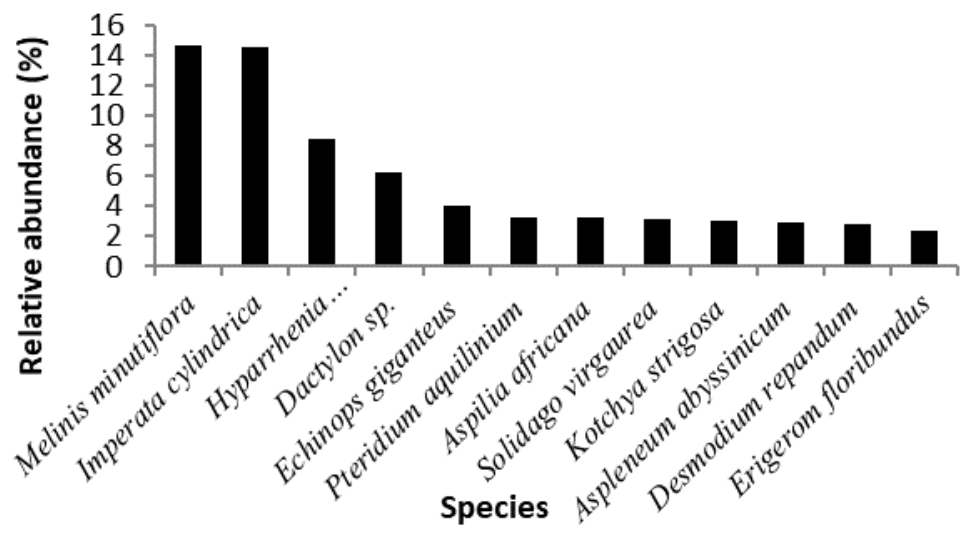

\section{Ecological Characteristics}

\section{Plant Growth Forms}

In regard to plant growth forms, the most common species were herbs (81\%), followed by shrubs (12\%), trees (6\%), and the least plant morphological type present were ferns (2\%) (Figure 6).

Figure 6. Percentage of plant growth forms

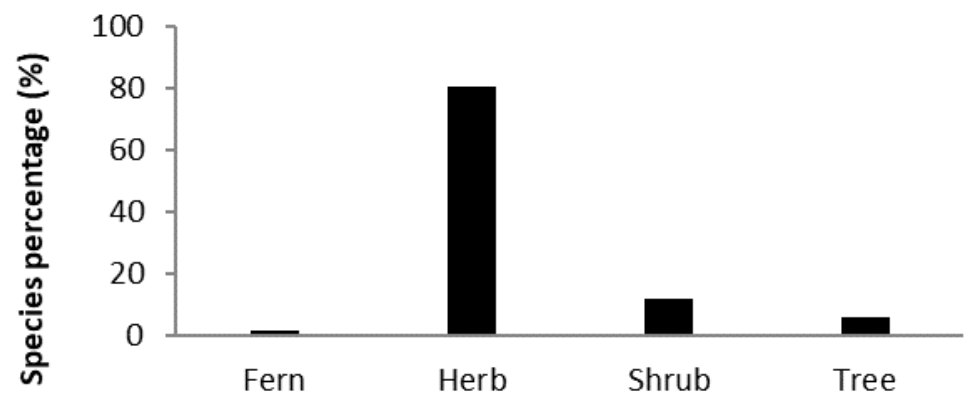

Growth forms

\section{Life Forms}

The most dominant life forms were the chamaephytes (38.93\%), followed by phanerophytes (21.85\%), and therophytes (12.61\%) (Figure 7). 
The least represented biological forms were the geophytes (8.40\%) and hemicryptophytes (7.56\%).

Figure 7. Percentage of plant life forms

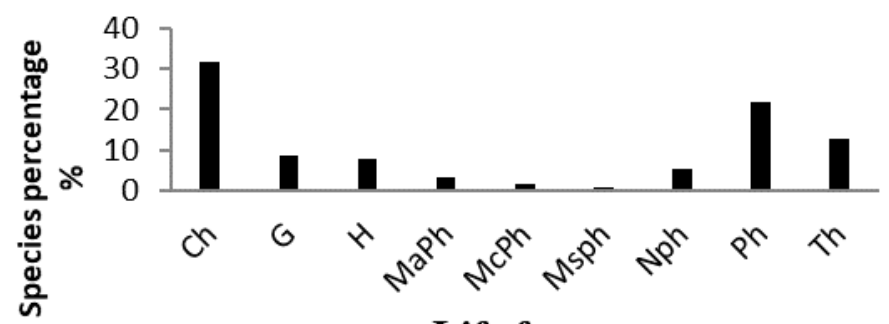

\section{Life forms}

Chamaephytes: Ch, Goephytes: G, Therophytes: Th, Hemicryptophytes: H, Phanerophytes: Ph, Macrophanerophytes: MaPh, Mesophanerophytes: MsPh, Microphanerophytes: McPh, Nanophanerophytes: NPh, liscent phanerophytes: PhL

\section{Type of Diaspores}

This information highlights the ability of species to colonize new sites, to regenerate, and persist locally. The pogonochores and sclerochores were the most dominant diaspores type because they both had the same values of $22.69 \%$. This was followed by the acanthochores and sporochores that also had values of $2.52 \%$ (Figure 9 ).

Figure 9. Percentage type of diaspores

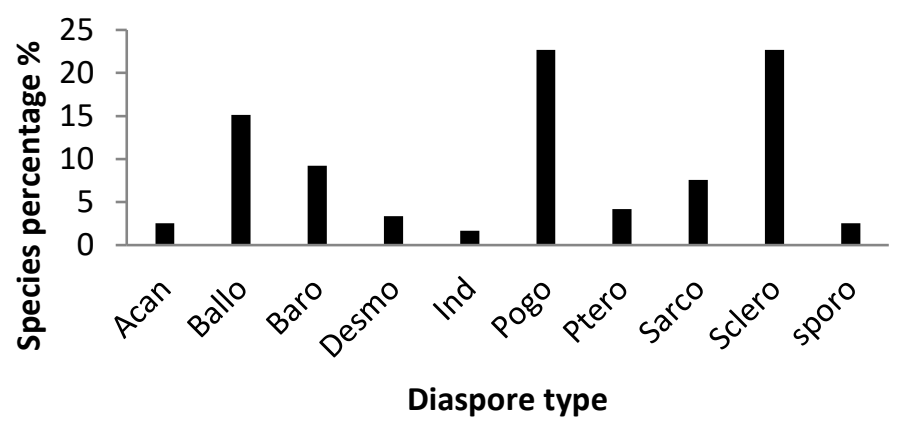

Sclerochores: Sclero, Pterochores: Ptero, Pogonochores: Pogo, Sporochores: Sporo, Acanthochores: Acan, Sarcochores: Sacro, Desmochores: Desmo, Ballochores: Ballo, Barochores: Baro

\section{Seed Dispersal Syndromes}

The majority of the taxa in the study plots was dispersed by wind anemochory (50.42\%), followed by autochory (23.52\%), and the least was epizoochory (5.88\%) (Figure 8). 
Figure 8. Percentage seed dispersal modes

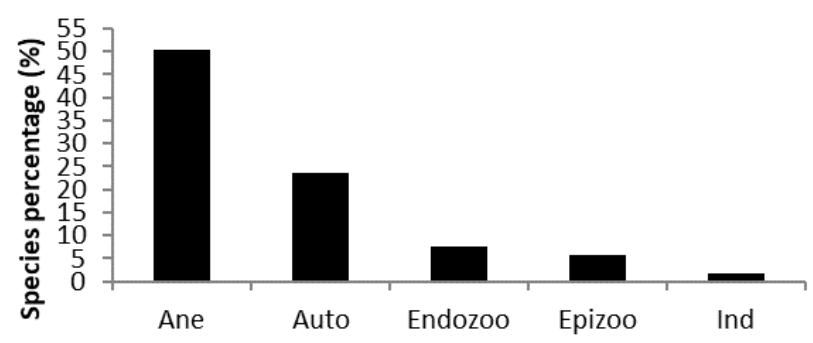

Dispersal syndromes

Anemochory: Ane, Autochory: Auto, Endozoochory: Endozoo, Epizoochory: Epizoo, Not determined: Ind

\section{Phytogeographical Distribution}

Studies on the geographical distribution of plants species indicated that the total flora was composed mostly of pantropical species (9.41\%), followed by afro-tropical elements (25 species, 21.01\%), Cosmopolitan (9.24\%), and the rest of the species had representations less than 8 species (Figure 10).

Figure 10. Percentage of phytogeographic distribution

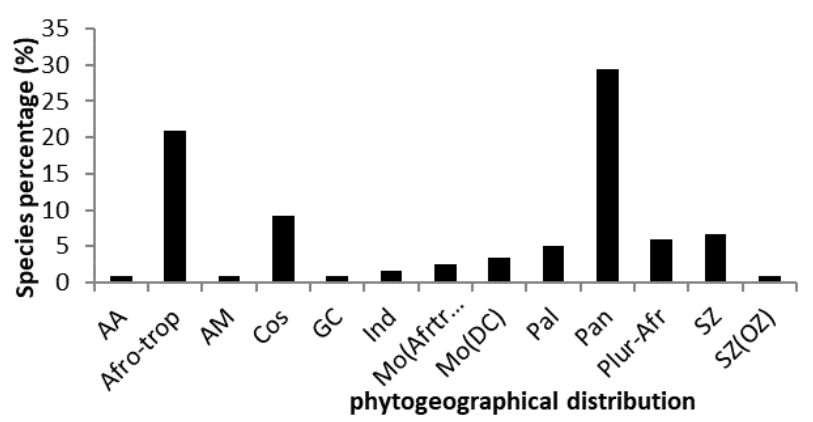

Afro-American: AA, Afro-Tropical: Afro-trop, Afro-Magaches: AM, Cosmopolitan:

Cos, Guineo-Congolian: GC, Paleotropical: Pal, Pantropical: Pan, Pluriregional African: Plur-Afr, Sudano-Guinean, Sudano-Zambezian: SZ(OZ), Species from the mountains of tropical Africa: Mo(Afrtrop), Only in Cameroonian mountain: Mo(DC), Not determined: Ind

\section{Leaf Sizes}

Leaf sizes are a response to altitude, local weather conditions, and regional orographic gradient. The most common leaf sizes were microphylls (26.05\%), followed by notophylls (25.21\%), and mesophylls (19.33\%) (Figure 11). However, the leptophylles (1.68\%) had the least representation. 
Figure 11. Percentage of leaf sizes

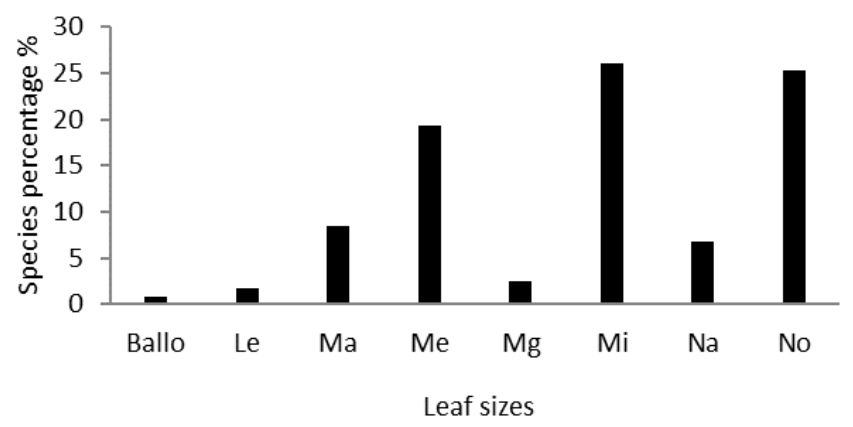

Leptoophylls: Le, Macrophylls: Ma, Mesophylls: Me, Megaphylls: Mg, Microophylls: Mi, Nanophylls: Na, Notoophylls: No

\section{Discussion}

Asteraceae, Poaceae, and Fabaceae have emerged as the common families in the investigated area after a total of 121 plant species belonging to 91 genera and 34 families (APG III) were recorded. These findings are similar with the results of Ramirez (2007) in Venezuela, Akossoua and Kouassi (2010) in Abidjan in Ivory Coast, Masharabu (2010) in Burundi, Qureshi (2014) in Pakistan, Khalid et al. (2020) in Pakistan, and Helvetas (2001) in Cameroon. Helvetas (2001) stated that the high presence of species of the Gramineae family is explained by the fact that savannahs are grass-dominated ecosystems. Moreover, Poaceae taxa have a high tilling potential and a high regrowth rate after grazing if environmental conditions are favourable.

The abundance of Asteraceae can be attributed to their great range of ecological tolerance and great capacity of seed dispersion (Ramirez, 2007). The species of Poaceae and Asteraceae due to their wide ecological amplitude are diverse in their habitat occurrence. The high value of the Shannon-Weaver diversity index and the Pielou equitability index showed that this site was diversified. The diversity could be explained by the diversity of the observed biotope diversity (lowland, hilltop and slope zone).

Also, the domination of this study sites by herbs corresponds to the works carried out in such zones which show that savannas are ecosystems dominated by herbs (Eiten, 1986; Huntley \& Walker, 1982; Inyat et al., 2018; khansa et al., 2019). Human beings and bush fires maintain this ecosystem.

Information on biological life forms makes it possible to appreciate the detail of phytoclimates and ecological evolution (Trochain, 1966). It also gives the indications on the structure, physiognomy, and adapting strategies of a community (Gillet, 2000). The high percentage of chamaephytes seen in this study is linked to their ability of stress tolerance. The low representation of microphanerophytes and nanophanerophytes observed in this study shows that 
there are very minimal trees around E. giganteus. Geophytes are also present due to their biological form which is adapted to stress and perturbation environments (Julve, 1989). The proportions of chamaephytes and therophytes indicate the possibility of plant adaptation to environmental factors. The important consideration of phanerophytes (megaphanerophytes, mesophanerophytes, microphanerophytes, nanophanerophytes, liana phanerophytes) is their strategy of adaptation which corresponds to their strategy of competition. In the study area, bush fire is a high anthropogenic stress faced by plant vegetation. As a result, they have a series of adaptation strategies to assure their survival (Masharabu et al., 2010) These strategies include the capacity to reject strains, the existence of underground organs (bulbs and rhizomes), thick backs to resist high temperatures, and liberation of grains after bush burning (Lepart \& Escarre, 1983). This study is in line with that of Schmidt (2005) where biological forms represent both structural parameters and varied environmental condition.

From the different categories of diaspores, according to the classification of Molinier and Muller (1938) in conformity with the works of Habiyaremye (1997) and Bangirinama (2010), it is observed that savannas are dominated by anemochores (sclerochores, pterochores, pogonochores and sporochores). This is the reason for the trend around E. giganteus, and anemochory is the mode of dispersal in the study. Furthermore, anemochory is a principal strategy for diaspora dispersal in open canopy areas (Senterre, 2005; Bangirinama et al., 2008). According to Charles-Dominique (1995), the efficiency of grain dispersal contributes to forest regeneration. The high percentage of species widely distributed indicates the openness of the flora to external influences. Thus, these species are mostly those of disturbed zones. A high percentage of phytogeographic distribution can be an indication of degradation since the flora is losing its specificity (Devineau \& Fournier, 1997). The abundance of widely distributed species (pantropical) and continental distribution (Afro-tropical) indicates disturbed vegetation. This shows a certain degree of local flora changes and reflection history of global floristics effects of human occupation (Lubini, 1982). Concerning life sizes, Mesophylls, microphylls, and notophylls are the most frequent in this study. This is influenced by heat, humidity, light, and wind. According to Ohsawa (1995), in sub-tropical forests, intact zones are dominated by trees with notophylls and mesophylls leaves. On the other hand, in stress zones, there are plants with notoophylls and microphylls leaves.

\section{Conclusion}

The current study provides an insight into the floristic diversity, composition, and ecological spectrum of the species that live in association with E. giganteus. Asteraceae, Poaceae, and Fabaceae were the dominant 
families. Phanerophytes were the most frequent life form followed by chamaephytes and therophytes. The most dominant leaf sizes were mesophylls, microphylls and notophylls. Anemochory was the main strategy of dispersion followed by zoochory. Chorological analysis revealed that the afro-tropical species was the most dominant chorotype, followed by pantropical and paleotropical species. The harvesting of E. giganteus does not only threaten its sustainability, but the sustainability of other plant species as well. The exploitation method for E. giganteus is by digging. In the process of digging, all other species around it is being destroyed. Thus, it is of significant importance that $E$. giganteus should be regenerated at a large-scale and domesticated for a sustainable management plan.

\section{References:}

1. Aghofack- Nguemezi, J. \& Tatchago, V. (2010). Effects of Fertilizers Containing Calcium and/or Magnesium on the Growth, Development of Plants and the Quality of Tomato Fruits in the Western Highlands of Cameroon. International Journal of Agricultural Research. 5: 821831.

2. Akossoua, F., Adou, Y., Ipou, J., \& Kamanzi, K. (2010). Diversité floristique des zones côtières pâturées de la Côte d'Ivoire : cas du cordon littoral Port-Bouët-Grand-Bassam(Abidjan). Science et Nature. 7(1): 69 - 86.

3. APG III (2009). An update of the Angiosperm Phylogeny Group classification for the orders and families of flowering plants: APG III. Botanical Journal of the Linnean Society, Vol 161: 105 - 121.

4. Aswingnue, L. (2003). Human adaptation to physical environment, case study: Tubah Subdivision. A DIPES research project. University of Yaounde I. 1-46.

5. Aubreville A. (éd.). coll. Multiples. (1963-1998) : Flore du Cameroun. Muséum National d'Histoire Naturelle, Laboratoire de Phanérogamie, Paris, volume 1 (1963) to 34 (1998).

6. Bangirinama, F., Bigendako, M., \& Lejoly, J. (2008). Ecologie du paysage et diversité végétale de la zone environnant la forêt de Mpotsa (Burundi). Revue de l’Université du Burundi. Série Sciences Exactes. 23: 71-89.

7. Braun-Blanquet (1932). Plant sociology. The study of plant communities. New-York, Conservation, Management and Sustainable Use. Occasional papers of the IUCN, Species Survival Commission $\mathrm{N}^{\circ} 6,242 \mathrm{p}$.

8. Charles-Dominique, P. (1995). Interactions plantes-animaux frugivores, conséquences sur la dissémination des grains et la régénération forestière. Revue Ecologique. (Terre Vie), 50: 223 - 235. 
9. Dansereau, P. \& Lems, K. (1957). The grading of dispersal types in plant communities. Contributions de l'Institut de Botanique de Montréal. $71: 1$ - 52.

10. Devineau, J. \& Fournier, A. (1997). La flore et la végétation. In: Devineau J.L., Fournier A., Kaloga B (eds.), Les sols et la végétation de la région de Bondoukuy (Ouest burkinabé), présentation générale et cartographie préliminaire par télédétection satellitaire (SPOT), ORSTOM éditions. pp. 29 - 47.

11. Eiten, G. (1986). The use of the term "savanna". Tropical Ecology. 27:10-23.

12. Garnatje, T., Valle, J., Garcia, S., Hidalgo, O., Sanz, M., Canela, M., \& Siljak-akovlev, S. (2004). Genome size in Echinops L. and related genera (Asteraceae Cardueae): karyological, ecological and phylogenetic implications. Biological Cell. 96 (2):117-24.

13. Gillet, F. (2000). La phytosociologie synusiale intégrée : Guide méthodologique. Documents du laboratoire d'écologie végétale. Université de Neuchâtel, 68p.

14. Habiyaremye, M. (1997). Etude phytocoenologique de la dorsale orientale du lac Kivu (Rwanda). Musée Royal.de l’Afrique Centrale. Tervuren, Belgique. Annales Sciences Economiques. 24: 276 p.

15. Hamzaoglu, E. (2005). The steppe vegetation of Dinek Mountain(kirikkale) Gazi University Journal of Science. 17:1-13.

16. Helvetas Cameroon (2001). Tubah rural council monographic study.

17. Huntley, B.J. \& Walker B.H. (1982). Ecology of tropical savannas. Ecological Studies 42. Springer Verlag, Berlin.

18. Inayat, U.R., Aftab, A., Zafar, I., Farhana, I., Niaz, A., Muhammad, A., Jan, A., Abdul, M., Robbie, H., \& Rainer, B. (2018). First insights into the floristic diversity, biological spectra and phenology of manoor valley, Pakistan. Pakistan Journal of Botany. 50(3): 1113-1124.

19. Julve, P. (1989). Sur les relations entre les types biologiques et stratégies adaptatives chez les végétaux. Bulletin d'Ecologie. 20(1): 79-80.

20. Khalid, R., Muhammad, F., Abbas Hussain, S., Zafar. I., Jan, A., Manzoor, H., Ghulam, M., Azhar, M., \& Nehafta, B. (2020). Floristic composition, community syntaxonomy and ordination of Guzara (unprotected) forests of Hilkot range, District Mansehra, KP, Pakistan. International Academy of Ecology and Environmental Sciences. 10(1): 8-21.

21. Khansa, A., Khalid, R., Abbas, H., Muhammad, F., Manzoor, H., \& Ghulam, M. (2019). A comprehensive survey of floristic diversity evaluating the role of institutional gardening in conservation of plant biodiversity. International Journal of Biosciences. 14(3): 325-339. 
22. Kouassi, A., Adou, Y., Ipou, I., \& Kamanzi, K. (2010). Diversité floristique des zones côtières pâturées de la Côte d'Ivoire : cas du cordon littoral Port-Bouët-Grand-Bassam (Abidjan). Sciences \& Nature. 7(1): 69-86.

23. Krishnamurthy, Prakash, Y., Nanda, H., Krishnappa, A., Dattaraja, H.S., \& Suresh, H.S. (2010). Vegetation structure and floristic composition of a tropical forests in Bhadra Wildlife Sanctuary, Karnataka. India Tropical Ecology. 51(2): 235-246.

24. Kumar, A., Bruce, G., \& Ajai, S. (2006). Tree species diversity and distribution patterns in tropical forests of Garo Hills. Current Science. 91:1370-81.

25. Lepart, J. \& Escarre, J. (1983). La succession végétale, mécanismes et modèles : analyse bibliographique. Bulletin Ecologique. 14(3): 133 178.

26. Lubini, A. (1982). Végétation messicole et postculturale des sousrégions de Kisangani et de la Tshopo (Haut-Zaïre). Thèse de doctorat, Université de Kisangani, 489 pp.

27. Masharabu, T., Noret, N., Lejoly, J., Bigendako, M., \& Bogaert, J. (2010). Etude comparative des paramètres floristiques du Parc National de la Ruvubu, Burundi. Geography-Ecology-Tropic. 34: 29 44.

28. Menut, G., Lamaty, P., Weyerstahl, H., Marschall S., \& Amvam Zollo, P. (1997). Aromatic plants of tropical Central Africa. Part XXXI. Tricyclic sesquiterpenes from the root essential oil of Echinops giganteus var.lelyi C. D. Adams. Flavour Fragrance Journal. 12(6): 1026-1099.

29. Molinier, R. \& Muller, P. (1938). La dissémination des espèces végétales. Revue Générale de Botanique. 50: 53-72.

30. Ngamo, T., Ngatanko, I., Ngassou, M., Mapongmestem, P., \& Hance, T. (2007). Insecticidal efficiency of essential oils of 5 aromatic plants tested both alone and in combination towards Sitophilus oryzae (L.) (Coleoptera: Curculionidae). Research Journal of Biological Sciience. 2 (1): 75-80.

31. Ngwa, J. (1979). A new geography of Cameroon. Longman group Ltd London.1-200.

32. Noumi, E. (1984). Les plantes à épices, à condiments et à aromates du Cameroun. Thèse de Doctorat en Sciences Biologiques, Université de Yaoundé. 22-24.

33. Ohsawa, M. (1995). Latitudinal comparison of altitudinal changes in forest structure, leaf-type, and species richness in humid monsoon Asia. Vegetatio. 121: 3 - 10. 
34. Onana, J. (2011). The vascular plants of Cameroon. A taxonomic checklist with IUCN assessments. Compiled and edited by Jean Michel Onana, $195 \mathrm{p}$.

35. Pérez, S., Ramos-López, M., Zavala-Sánchez, M., \& Cárdenas-Ortega, N. (2010). Activity of essential oils as a biorational alternative to control coleopteran insects in stored grains. Journal of Medicinal Plants Research. 4 (25): 2827-2835

36. Qureshi, R., Shaheen, H., Ilyas, M., Ahmed, W., \& Munir, M. (2014). Phytodiversity and plant life of Khanpur Dam, Khyber Pakhtunkhwa, Pakistan. Pakistan Journal of Botany. 46 (3): 841-849.

37. Ramirez, N., Nelda, Dezzeo, N., \& Chacon, N. (2007). Floristic composition, plant species abundance, and soil properties of montane savannas in the Gran Sabana, Venezuela. Flora. 202: 316-327.

38. Raunkiaer, C. (1934). The life forms of plants and statistical plant geography. Clarendon Press, Oxford, London, 632 p.

39. Schmidt, M., Kreft, H., Thiombiano, A., \& Zizka, G. (2005). Herbarium collection and field data-based plant diversity maps for Burkina Faso. Diversity and Distribution. 11: 509 - 516.

40. Senterre, B. (2005). Recherches méthodologiques pour la typologie de la végétation et la phytogéographie des forêts denses d'Afrique tropicale. Thèse de Doctorat, Université Libre de Bruxelles, Belgique, $345 \mathrm{p}$.

41. Simpson, E.H. (1949). Measurement of diversity. Nature, vol 163: 688

42. Suh, C., Meka, S., Ngome, A., Neba, D., Kemngwa, I., Sonkouat, A., \& Njualem, D. (2015). Effects of organic and inorganic fertilizers on growth and yield of potato (Solanum tuberosum L.) in the western highlands of Cameroon. International Journal of Development Research. 5 (2): 3584-3588.

43. Tchatat, M. (1999). Produits Forestiers Autres que le Bois d'œuvre (PFAB): place dans l'aménagement durable des forêts denses humides d'Afrique Centrale. Projet regional de capitalisation et transfert des recherches sur les écosystèmes forestiers de l'Afrique humide. Série FORAFRI. Document 18.Yaoundé.

44. Tel, A., Tatli, A., \& Varol, O. (2010). Phytosociological structure of Nemrut Mountain (Adiyaman/Turkey). Turkish Journal of Botany. 34: 417-434.

45. Tene, M., Tane, P., Sondengam, B.L., \& Connolly, J. (2004). “Lignans from the roots of Echinops giganteus,” Phytochemistry. 65 (14): 21012105.

46. Trochain, J. (1966). Types biologiques chez les végétaux intertropicaux (Angiospermes). Mémoire Société Botanique de France : 186 - 196. 
47. Van der Zon, A. (1992). Graminées du Cameroun, volume I. Phytogéographie et pâturages. Wageningen Agric. Univ. Papers 92-1, $86 \mathrm{p}$.

48. White, F. (1986). La végétation de l’Afrique. Mémoire accompagnant la carte de végétation de l'Afrique. UNESCO/AETFAT/UNSO. ORSTOM \& UNESCO, Paris, France, 384 p.

49. Wouokoue, T., Anjah, G., Nguetsop, V., \& Fonkou T. (2017a). Floristic diversity of the savannah ecosystems in three altitudinal zones of the Bambouto Mountains, West Cameroon. Cameroon Journal of Biological and Biochemical Sciences. 25: 52-59.

50. Wouokoue, T., Nguetsop, V., \& Fonkou, T. (2017b). Floristic diversity of Western Highlands savannas of Cameroon. International Journal of Current Research in Biosciences and Plant Biology. 4: 7-13. 